\title{
K-Ar Ages and Paleosecular Variation of Direction and Intensity from Quaternary Lava Sequences in the Ruapehu Volcano, New Zealand
}

\author{
Hidefumi TANAKA ${ }^{1}$, Ken'ichi KaWAmura ${ }^{2}$, Keisuke NAGAO $^{3}$, and Bruce F. Houghton ${ }^{4}$ \\ 1 Faculty of Education, Kochi University, Kochi 780, Japan \\ 2 Earth and Planetary Sciences, Tokyo Institute of Technology, Meguro-ku, Tokyo 152, Japan \\ 3 Institute for Study of the Earth's Interior, Okayama University, Misasa, Tottori-ken 682-01, Japan \\ 4 Institute of Geological and Nuclear Sciences, Wairakei Research Center, Wairakei, Taupo, New Zealand
}

(Received January 4, 1996; Revised October 21, 1996; Accepted October 28, 1996)

Andesite lava sequences of the Quaternary Ruapehu Volcano, New Zealand were studied to obtain paleosecular variations, both direction and intensity.

$\mathrm{K}$-Ar dating was performed on 7 lavas of the younger Whakapapa Formation and 22 lavas of the older Te Herenga Formation. Initial experiments by the isotope dilution method using an ${ }^{38} \mathrm{Ar}$ spike were unsuccessful on the younger lavas, while an amplitude method in which the abundance of $\mathrm{Ar}$ is estimated from a peak height of mass spectrum gave consistent results of $32 \pm 12 \mathrm{ka}$ after the correction of the Ar isotopic ratios for mass dependent fractionation. The latter method also gave a more accurate result of $229 \pm 35 \mathrm{ka}$ for the older group. No significant relationship was observed in age versus stratigraphy for the $250 \mathrm{~m}$ thick older lava section. This suggests a short time span, less than the errors of dating, for the lava accumulation.

Primary paleodirections were easily obtained, after cleaning by both AF and thermal demagnetization, from all lavas except two in which a possible effect of lightning was suspected. Paleointensity experiments, using mainly the Shaw method, were made on 15 lavas which showed good stability to thermal demagnetization. In the analysis of the Shaw results, the correction method of Kono (1978) was applied, since most samples showed changes in ARM capacity after heating. The double heating technique of Tsunakawa and Shaw (1994) was also applied to some lavas, and was useful to discriminate erroneous data when inconsistent results were obtained. Serial correlation was not detected in the paleodirections of any series of the lavas. In spite of the random appearance of the data, the dipole direction was not obtained from the older section which included 20 data.

\section{Introduction}

Paleosecular variation from a sequence of lavas which accumulated successively may give a good picture of the geomagnetic field viewed in time series. Such paleomagnetic records from lava sequences are usually very reliable owing to the stable nature of the remanence of volcanic rocks, and absolute paleointensities can often be recovered also. Good examples are the studies of the transitional field as illustrated in the studies of the Steens Mountain lavas in Oregon (Mankinen et al., 1985). Even if the lava accumulation rate is low and random, the dataset may still give a good opportunity to study the statistical features of the geomagnetic field as shown in the studies of the Icelandic lavas (e.g., Kristjánsson, 1985). This paper reports a study of paleosecular variation obtained from successive lava flows in New Zealand. Both direction and intensity were studied at the same time, in order to give a better picture of the secular variation style of the past geomagnetic field. 


\section{Geology and K-Ar Dating}

Mt. Ruapehu is one of five volcanoes in the Tongariro Volcanic Centre (Fig. 1(a)) which lies at the southern end of Taupo Volcanic Zone (TVZ). TVZ is the largest active volcanic belt in New Zealand, and covers a region of $180 \mathrm{~km}$ long and $60 \mathrm{~km}$ wide with a strike of $037^{\circ}$. It is generally considered that the present-day volcanism of TVZ is directly related to the subduction zone which surfaces some $250 \mathrm{~km}$ to the southeast (Cole, 1986). The central part of TVZ is mostly silicic volcanic systems while the northern and southern parts contain the andesitic volcanoes of White Island and the Tongariro Volcanic Centre.

Mt. Ruapehu is very active with a long record of historical activity including the latest eruption in 1995-96 (Wilson, 1996). It consists of a volcanic cone dominated by andesitic sheet lavas and autobreccias, and a surrounding ring plain of pyroclastic deposits and reworked material eroded from the cone. The volcanic cone comprises four formations, each corresponding to a conebuilding episode (Fig. 1(b)) the first of which initiated about 250 ky ago (Hackett and Houghton, 1989). Excellent exposures of successive lava flows and fall deposits are found in the steep gullies which have been formed by glacial erosion. Only a few radiometric ages have been reported. A single rock specimen from near the top of the Te Herenga Formation gave an age of $0.23 \pm 0.06$ $\mathrm{Ma}$ and two specimens from the Mangawhero Formation gave 24 and $26 \mathrm{ka}$ (Stipp, 1968).

Samples were collected from 20 lava flows and one dyke of the oldest Te Herenga Formation at Whakapapanui Gorge (indicated by B in Fig. 1(b)) and 7 lava flows of the youngest Whakapapa Formation at the Whakapapa ski field (indicated by A in Fig. 1(b)). The former involves two sections at the western side of the Whakapapanui gorge and at the Khyber Pass of the Te Herenga Ridge, which are $400 \mathrm{~m}$ apart. The dyke is at the Meads Wall near the western edge of the Whakapapa Gorge. The early paleomagnetic work of Cox (1969) included three lavas from Mt.

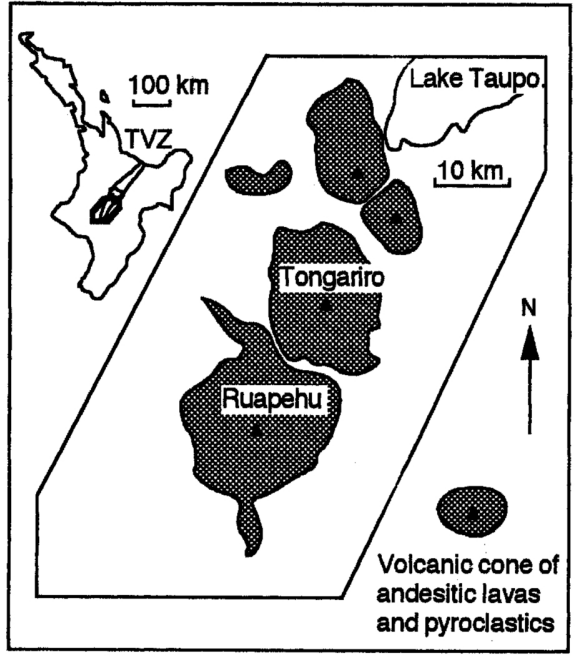

(a)

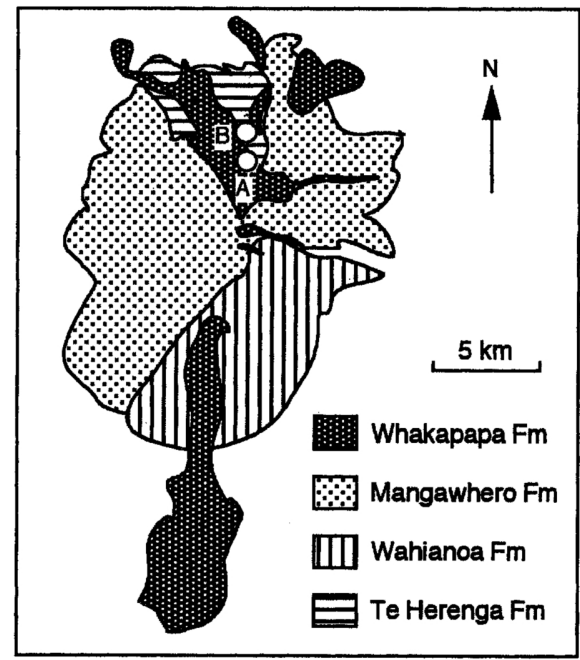

(b)

Fig. 1. Map showing andesite volcanos of the Tongariro Volcanic Centre, where TVZ is the Taupo Volcanic Zone (a), and simplified geological map of Mt. Ruapehu with the locations of the lava sections (b). The site locations of the younger Whakapapa Formation and the older Te Herenga Formation are indicated by $\mathrm{A}$ and B, respectively. Both figures are modified after Hackett and Houghton (1989). 
Ruapehu. One of them (NZ-25) is from the same part of the upper section of the older Te Herenga Formation sampled in this study. It is difficult, however, to identify it with a particular site of this study. Five cores, $2.5 \mathrm{~cm}$ in diameter, were drilled from each lava, and one specimen usually of $2.2 \mathrm{~cm}$ height was used for K-Ar dating. First a thin section was made and the presence of clay minerals was checked optically. Negative results were obtained for all lavas, proving the freshness of the samples. Next whole samples were powdered to 60-80 mesh. Half of the powder was used for the measurement of Ar content, and the other half was further ground and used to measure K content.

Measurements of $\mathrm{K}$ content were made by a flame photometer (FIP-3M) at the Earthquake Research Institute of University of Tokyo following the conventional method (Dalrymple and Lanphere, 1969). Two independent measurements were made on each sample and the errors were calculated as a half of the difference between the two values. Two standard samples were involved in the experiments to check the reliability of the measurements. They are a granodiorite (JG-1) and a basalt (JB-1), which have been frequently measured at various laboratories in Japan (Ando et al., 1971).

The older series, the Te Herenga Formation, gave $\mathrm{K}$ content of around $0.5 \mathrm{wt} \%$ while the younger series, the Whakapapa Formation, gave $\mathrm{K}$ content of more than $1 \mathrm{wt} \%$. The measured $\mathrm{K}$ content of the standard samples are $1.10 \pm 0.04 \mathrm{wt} \%$ and $3.31 \pm 0.07 \mathrm{wt} \%$ for JB-1 and JG-1, respectively. These results are in excellent agreement with the optimal values for them of 1.18 $\mathrm{wt} \%$ and $3.28 \mathrm{wt} \%$, respectively.

Measurements of Ar content were made by two noble gas mass spectrometers (Modified VG5400) at the Institute for Study of the Earth's Interior, Okayama University. Two series of experiments were made, firstly by a conventional method using a spike of ${ }^{38} \mathrm{Ar}$, and secondly by an amplitude method which does not involve ${ }^{38} \mathrm{Ar}$ spikes but which determines the $\mathrm{Ar}$ content solely by the peak height assuming constant sensitivity of the machine. The latter method was first described by Gillot et al. (1979), and is widely used for dating ultra young volcanic rocks in which the content of radiogenic ${ }^{40} \mathrm{Ar}$ is extremely low (Nagao et al., 1991). One of the merits of this method is that the ${ }^{38} \mathrm{Ar} /{ }^{36} \mathrm{Ar}$ ratio of trapped $\mathrm{Ar}$ is obtained and we can use it to correct the effect of mass dependent fractionation of Ar which has often been recognized in volcanic rocks (Kaneoka, 1980). We here concentrate only on the results obtained by the latter method which are summarized in Appendix A.

The experiments included four measurements of a standard sample, YZ1-6, from Zao Volcano, Japan which has been frequently used to check inter-laboratory consistency of dating very young rocks (less than $1 \mathrm{Ma}$ ). The mean of the four ages, calculated assuming the mass fractionation, is $238 \pm 16 \mathrm{ka}$. If the mass fractionation is neglected, the mean age is $222 \pm 6 \mathrm{ka}$, which is in good agreement with the reported ones (210-227 ka; see compilation by Nagao et al., 1996) showing the high reliability of our data obtained in this work.

The Whakapapa Formation gave a mean age of $32 \pm 12 \mathrm{ka}$ based on seven measurements, involving a correction for the mass dependent fractionation of Ar. The obtained age is ultra young but seems to be reliable judging from the repeatability of the measurements. It is noted that seven out of the eight original measurements gave reasonable values if mass dependent fractionation is taken into account, while five out of the eight raw measurements values gave negative ages. The new age obtained in this study is older than the former estimate of 0-15 ka which was based on volcano-stratigraphic considerations (Hackett and Houghton, 1989). To obtain a more accurate age, methods, such as ${ }^{14} \mathrm{C}$ dating, more suitable for application to younger ages, are needed.

For the Te Herenga Formation, a mean age of $229 \pm 35$ ka was obtained from 28 measurements in which the effect of mass dependent fractionation of Ar was corrected. This is in good agreement with the few radiometric ages previously reported (Stipp, 1968). When the K-Ar age versus stratigraphy is examined for the 28 results of the Te Herenga Formation, unfortunately, there is no reasonable relation between age and the position of lava. We interpret this as showing that 
the lavas accumulated in a short time, within the error limits of the dating method. It is difficult to confine the best estimate of the time interval of the lava eruption. It will be shown, however, that the eruption rate was not so high as to record the trend of paleosecular variation because serial correlation was not detected among the paleodirections of each lava.

\section{Paleodirections}

Magnetic remanences were measured using a Schonstedt spinner magnetometer (SSM-1A). The natural remanent magnetization (NRM) of most lavas was stable to both alternating field (AF) and thermal demagnetization, and the determination of the primary remanence direction was usually straightforward after the removal of small secondary components at lower demagnetization steps. Two examples of orthogonal component plots (Zijderveld, 1967) of the progressive $\mathrm{AF}$ or thermal demagnetization are shown in Fig. 2(a). At two sites the samples suffered from
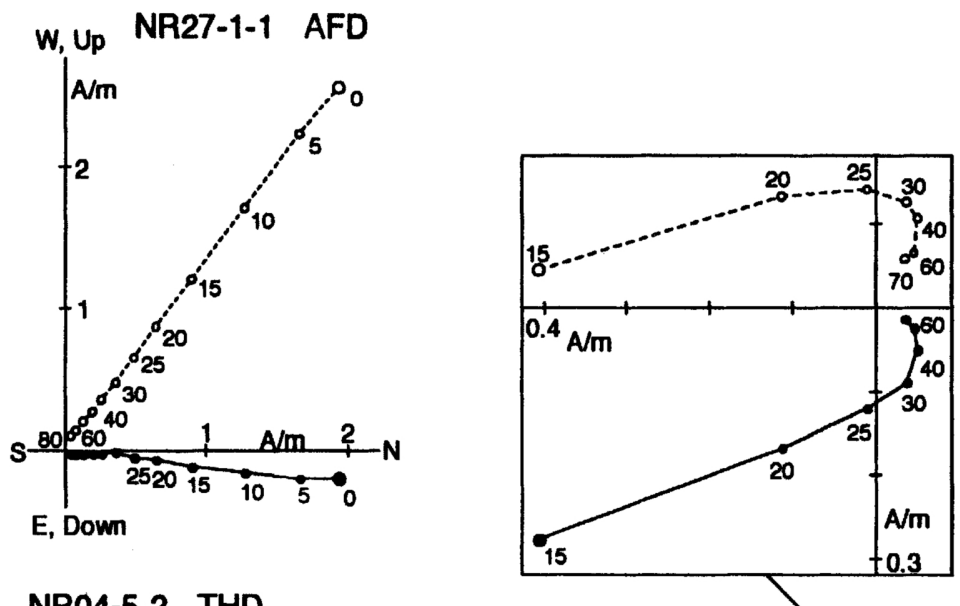

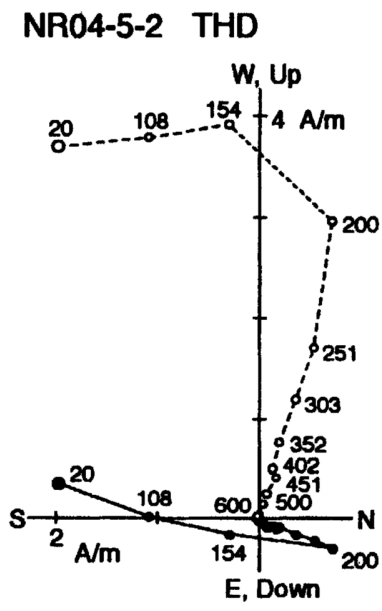

(a)

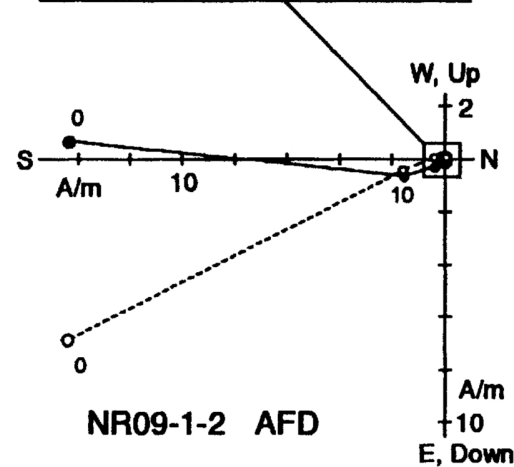

(b)

Fig. 2. Representative orthogonal plots of the progressive AF and thermal demagnetization for most lavas (a), and for two problem sites where extremely strong remanence was found, which apparently suffered from lightning (b). Reliable site mean paleodirection was obtained at one site of the latter by applying the great circle method. 
Table 1. Paleodirections and paleointensities from the Ruapehu Volcano, New Zealand.

\begin{tabular}{|c|c|c|c|c|c|c|c|c|c|c|}
\hline Lava & Inc & Dec & $\bar{N}$ & $\alpha_{95}$ & $\begin{array}{l}\text { Plat } \\
\left({ }^{\circ} \mathrm{N}\right)\end{array}$ & $\begin{array}{l}\text { Plon } \\
\left({ }^{\circ} \mathrm{E}\right)\end{array}$ & $\begin{array}{c}J \\
(\mathrm{~A} / \mathrm{m})\end{array}$ & $\begin{array}{c}F \\
(\mu \mathrm{T})\end{array}$ & $n / n 0$ & $\begin{array}{c}\text { VDM } \\
\left(\times 10^{22} \mathrm{Am}^{2}\right)\end{array}$ \\
\hline \multicolumn{11}{|c|}{ Whakapapa Formation $\left(39.3^{\circ} \mathrm{S}, 175.6^{\circ} \mathrm{E}\right)$} \\
\hline NR01 & -50.6 & 15.8 & 5 & 3.2 & 74.9 & 238.7 & $5.9 \pm 1.8$ & $46.7 \pm 6.3$ & $3 / 5$ & $8.97 \pm 1.22$ \\
\hline NR02 & -52.5 & 9.9 & 5 & 3.3 & 79.9 & 231.0 & $4.1 \pm 1.0$ & & & \\
\hline NR03 & -49.2 & 3.3 & 5 & 3.3 & 80.5 & 193.1 & $2.4 \pm 0.8$ & & & \\
\hline NR04 & -60.1 & 10.5 & 5 & 4.0 & 81.8 & 281.0 & $6.2 \pm 1.3$ & & & \\
\hline NR05 & -59.6 & 24.3 & 5 & 2.0 & 71.3 & 276.9 & $6.7 \pm 0.5$ & $54.5 \pm 3.6$ & $7 / 7$ & $9.38 \pm 0.63$ \\
\hline NR06 & -51.2 & 3.9 & 5 & 2.6 & 81.9 & 199.8 & $7.5 \pm 0.8$ & & & \\
\hline NR07 & -54.6 & 4.5 & 5 & 2.2 & 84.5 & 217.7 & $5.0 \pm 0.6$ & $59.3 \pm 3.0$ & $4 / 4$ & $10.85 \pm 0.54$ \\
\hline \multicolumn{11}{|c|}{$\begin{array}{c}\text { Te Herenga Formation }\left(39.2^{\circ} \mathrm{S}, 175.6^{\circ} \mathrm{E}\right) \\
\text { - dyke - }\end{array}$} \\
\hline NR08 & -69.4 & 36.3 & 5 & 6.2 & 61.8 & 306.8 & $4.0 \pm 1.9$ & $49.6 \pm 0.8$ & $2 / 2$ & $7.50 \pm 0.12$ \\
\hline \multicolumn{11}{|c|}{ - upper section - } \\
\hline NR13 & -53.0 & 16.6 & 5 & 3.8 & 75.6 & 247.8 & $1.9 \pm 0.7$ & - & $0 / 3$ & - \\
\hline NR14 & -59.6 & 21.1 & 5 & 9.5 & 73.8 & 276.4 & $2.0 \pm 1.7$ & & & \\
\hline NR15 & -55.8 & 18.3 & 5 & 5.8 & 75.2 & 260.0 & $1.5 \pm 0.4$ & 19.9 & $1 / 3$ & 3.59 \\
\hline NR16 & -49.2 & 22.1 & 6 & 0.6 & 69.7 & 245.4 & $40 \pm 40$ & & & \\
\hline NR10 & -41.9 & 25.5 & 5 & 9.3 & 63.7 & 238.3 & $6.3 \pm 3.1$ & $47.8 \pm 2.2$ & $2 / 2$ & $10.07 \pm 0.46$ \\
\hline NR11 & - & - & - & - & - & - & $18.7 \pm 6.7$ & & & \\
\hline NR12 & -48.9 & 18.5 & 5 & 3.5 & 72.1 & 239.3 & $8.2 \pm 0.7$ & & & \\
\hline NR17 & -51.5 & 26.9 & 5 & 2.8 & 67.1 & 255.9 & $3.3 \pm 1.0$ & 20.1 & $1 / 2$ & 3.82 \\
\hline NR18 & -57.8 & 19.6 & 5 & 2.5 & 74.7 & 268.9 & $2.2 \pm 1.1$ & $49.8 \pm 6.2$ & $2 / 2$ & $8.75 \pm 1.08$ \\
\hline NR30 & -57.3 & 18.2 & 5 & 1.9 & 75.7 & 265.9 & $2.7 \pm 1.3$ & 25.9 & $1 / 2$ & 4.59 \\
\hline NR31 & -56.8 & 21.1 & 5 & 2.6 & 73.4 & 265.9 & $2.4 \pm 0.5$ & & & \\
\hline \multicolumn{11}{|c|}{ - lower section - } \\
\hline NR19 & -48.3 & 18.4 & 5 & 3.2 & 71.9 & 237.8 & $1.6 \pm 0.2$ & & & \\
\hline NR20 & -46.0 & 28.1 & 5 & 5.1 & 63.8 & 247.1 & $4.6 \pm 1.6$ & & & \\
\hline NR21 & -52.0 & 42.2 & 5 & 8.6 & 55.5 & 267.9 & $1.0 \pm 0.1$ & - & $0 / 3$ & - \\
\hline NR22 & -43.1 & 27.2 & 5 & 4.7 & 63.1 & 241.9 & $1.5 \pm 0.2$ & & & \\
\hline NR23 & -51.5 & 7.1 & 5 & 7.0 & 80.8 & 216.8 & $4.7 \pm 3.3$ & 49.0 & $1 / 3$ & 9.32 \\
\hline NR24 & -71.5 & 29.9 & 5 & 10.9 & 64.0 & 316.3 & $5.8 \pm 2.2$ & $46.2 \pm 6.7$ & $6 / 7$ & $6.82 \pm 0.98$ \\
\hline NR27 & -52.4 & 8.7 & 5 & 3.5 & 80.6 & 226.5 & $4.0 \pm 0.6$ & - & $0 / 3$ & - \\
\hline NR28 & -55.3 & 19.3 & 5 & 5.1 & 74.4 & 259.0 & $1.9 \pm 0.4$ & & & \\
\hline NR29 & -60.5 & 24.0 & 5 & 2.8 & 71.6 & 280.3 & $2.1 \pm 0.3$ & $22.3 \pm 0.2$ & $2 / 8$ & $3.78 \pm 0.04$ \\
\hline
\end{tabular}

Lava, lava number in the descending order of stratigraphy; $N$, number of samples used to calculate the mean paleodirection; $\alpha_{95}$, circle of $95 \%$ confidence; Plat, Plon, latitude and longitude of virtual geomagnetic pole (VGP), respectively; $J$, intensity of NRM; $F$, paleointensity; $n, n 0$, numbers of samples which gave a successful result, and those used in the experiment, respectively; VDM, virtual dipole moment.

Grid references of sites: T20/313136(NR01,02), T20/313134(NR03), T20/313141(NR04,05), T20/310143(NR06,07), T20/311156(NR08), T20/311158(NR10-18,30,31), T20/312153(NR19-29).

extremely strong secondary components which were apparently caused by lightning. These are illustrated in Fig. 2(b).

Site mean paleodirections were usually determined from one primary direction revealed by thermal demagnetization plus four from AF demagnetization. Every demagnetization was made in a progressive way although the number of steps was usually reduced for non-pilot samples except for the sites which suffered from lightning. Great circle analysis by the method of McFadden and McElhinny (1988) was used to find a mean paleodirection from these two problem sites. At one site (NR16), owing to the divergent secondary directions, an accurate mean paleodirection was obtained without any survived linear remanence. At the other site (NR11), however, all great 
circle paths follow a similar trend, making it difficult to obtain an accurate primary direction. This is the only site in which a primary paleodirection was not recovered. All site mean paleodirections with the results of the Fisher statistics (Fisher, 1953) are given in Table 1, together with the results of the paleointensity experiments which are discussed in the next section.

\section{Paleointensities}

Paleointensities were determined mostly by the Shaw method (Shaw, 1974). Some lavas were also investigated by the Thellier method (Thellier and Thellier, 1959). Paleointensity experiments were made on fifteen lavas; usually two samples from each lava were investigated by the Shaw method. For some lavas, one or two extra samples were added, or applied to the Thellier method. Change of initial magnetic susceptibility versus temperature $(\chi-T$ curve) was measured by a Bartington magnetic susceptibility meter (MS-2). Only one lava gave perfect repeatability of the curves between heating and cooling. Most samples showed change between the heating and cooling curves to some extent (usually less than $30 \%$ ), nevertheless the paleointensity experiments were made on them.

In the Shaw method, thermally induced changes in the magnetic characteristics are checked by comparing the AF demagnetization curves of two ARMs induced before and after heating. In the original method, the criterion for a successful result was unity of the ratio of ARM1/ARM2. As some degree of rock magnetic alteration almost always occurs during heating, this criterion would give an extremely low success rate. To overcome this problem, Kono (1978) introduced a correction method in which the ratio of NRM/TRM was corrected by the ratio of ARM1/ARM2, supposing that the TRM capacity changes linearly with ARM capacity. Rolph and Shaw (1985) further developed this method to make the correction to $\triangle N R M / \triangle T R M$ at each demagnetization step by $\triangle A R M 1 / \triangle A R M 2$. All Ruapehu lava samples showed some change in ARM capacity as anticipated from the non-repeatable $\chi-T$ curves, and the correction of Kono (1978) was applied throughout the experiment.

Two or more samples from each lava were treated separately with different inducing fields for the implacement of TRM and ARM. Examples of successful results obtained from one of the younger lavas are shown in Fig. 3(a) and (b). The experiment on sample NR07-3-3 was made in a field of $30 \mu \mathrm{T}$ while NR07-4-2 was subjected to $50 \mu \mathrm{T}$. The slopes of the two NRM-TRM curves are quite different, but the paleointensities determined from the slopes, corrected by the slopes of ARM1/ARM2, and multiplied by the inducing fields, are in excellent agreement. Some samples were also investigated by the Thellier method. Figure 3(c) shows an Arai plot (Nagata et al., 1963) of the Thellier result made in a field of $50 \mu \mathrm{T}$ which is again in perfect agreement with those from the Shaw method.

Some lava flows, however, gave inconsistent results in the Shaw's experiment. Two conflicting paleointensities of $22 \mu \mathrm{T}$ and $48 \mu \mathrm{T}$ were obtained from one of the older lavas. Thellier's experiment, made on another five samples, were all unsuccessful. Additional experiments using the double heating technique introduced by Tsunakawa and Shaw (1994) were made on those lavas which gave problematic results. Using some historical standard samples, they noticed that erroneous paleointensities, which were sometimes accepted by the conventional criteria, can be rejected if one more heating cycle is examined. Figure 4(a) shows a result of the first round experiment made on another sample in a laboratory field of $20 \mu \mathrm{T}$. The new sample gave a paleointensity of $22 \mu \mathrm{T}$ which is exactly the same value as one of the previous results. Figure 4 (b) shows the positive result of the second round experiment. A TRM/TRM2 ratio of 1.04 was obtained from the slope of TRM-TRM2 of 1.10, after correcting for an ARM2/ARM3 ratio of 1.06. The double heating test was positive within the experimental error of $\pm 5 \%$. We concluded a mean paleointensity of $22.3 \mu \mathrm{T}$ for this lava.

Another example of the application of the double heating test in the Shaw method is illus- 


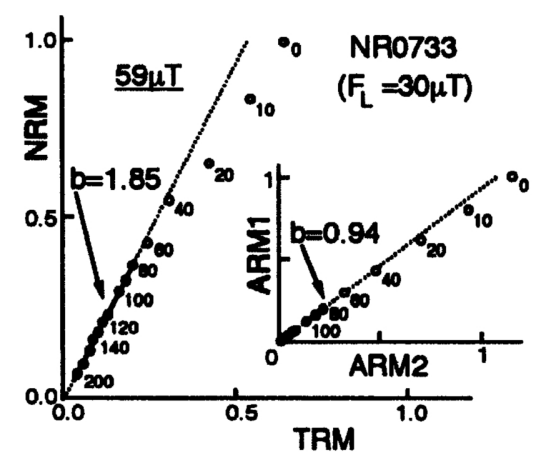

(a)

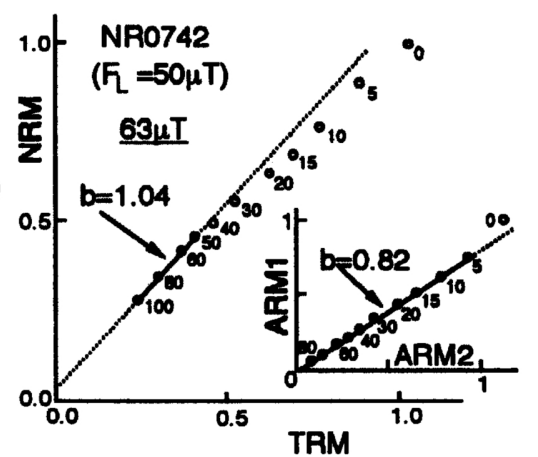

(b)

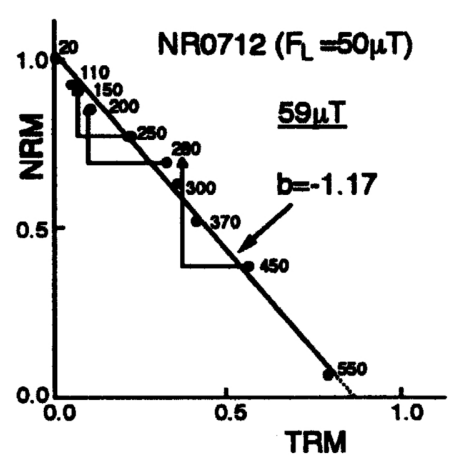

(c)

Fig. 3. Examples of good consistency in paleointensity experiments made to a lava of the Whakapapa Formation (32 ka). Results from Shaw method with different laboratory fields are shown in (a) and (b), and an Arai plot from Thellier method is shown in (c).

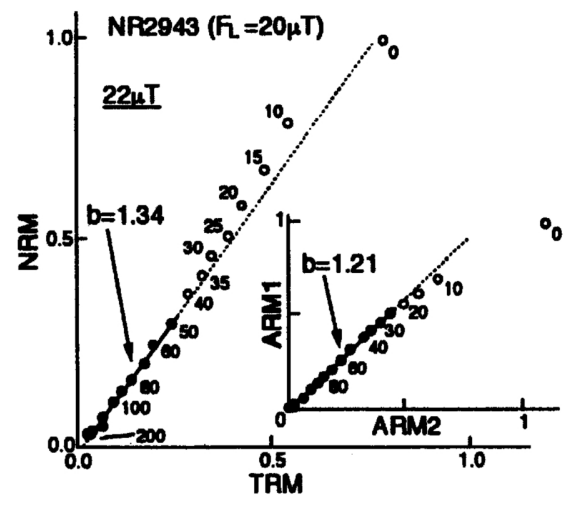

(a)

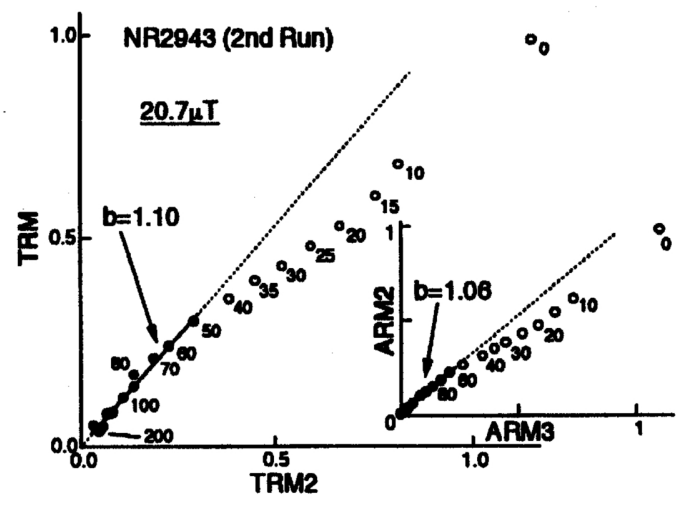

(b)

Fig. 4. Result of the double heating test by Tsunakawa and Shaw (1994) applied to a lava which showed inconsistent results of paleointensity $(22 \mu \mathrm{T}$ and $48 \mu \mathrm{T})$. First run with a laboratory field of $20 \mu \mathrm{T}$ is shown in (a), and in the second run (b) a correct value of the laboratory field was obtained within $4 \%$ difference.

trated in an experiment on one of the older lavas. In the early stage of the study, two samples were exposed to different TRM-inducing fields. These samples gave paleointensities of 8 and $10 \mu \mathrm{T}$, which are in good agreement but are very small for the latitude of Mt. Ruapehu. The results were, however, dubious because both samples showed large changes in the ARM1/ARM2 ratio; 0.30 and 0.54 . As an additional study, another sample was exposed to a field of $20 \mu \mathrm{T}$, then the double heating test was made. In the first round experiment, a paleointensity of $6 \mu \mathrm{T}$, which is in agreement with the previous results was obtained, as shown in Fig. 5(a). The second round experiment, however, gave an erroneous value of TRM/TRM2 of 1.17, after correcting for an ARM2/ARM3 ratio of 1.01, as shown in Fig. 5(b), indicating that these small paleointensity values should be rejected.

The success rate of the Shaw experiment was $53 \%$ (19 out of 36 ), while that of the Thellier's experiment was $65 \%$ (13 out of 20 ). Without the double heating technique by Tsunakawa and 


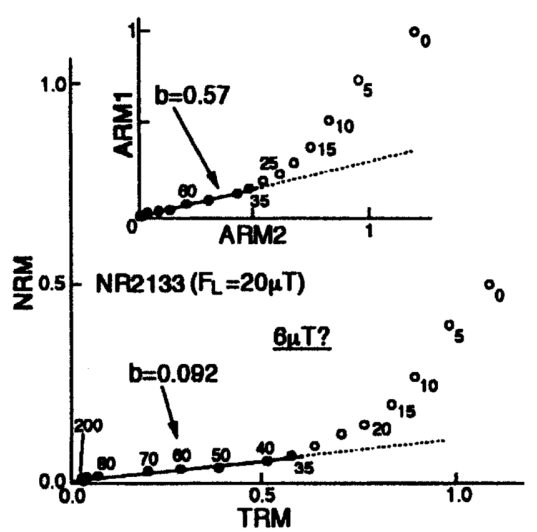

(a)

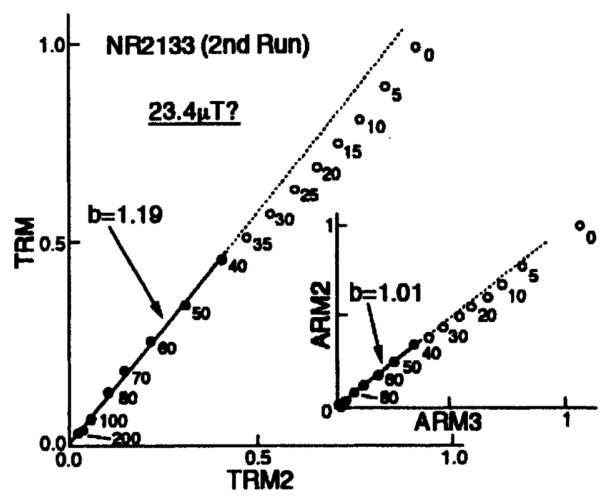

(b)

Fig. 5. Example of a negative result of the double heating test. The paleointensity of $6 \mu \mathrm{T}$ obtained from the first run (a) was rejected because the second run (b) does not give a correct value of the laboratory field (17\% higher).

Shaw (1994), the former would have been very high. A success rate closer to that of the Thellier's method rather indicates effectiveness of the technique. Site mean paleointensities are included in Table 1, and all results of specimen level are summarized in Appendix B.

\section{Discussion}

In a past study by Pesonen and Halls (1983), the idea of double heating was also applied to the Thellier method, in which they claimed that a successful second run proves the validity of the obtained paleointensity. However, it should be noted that a successful second run is surely a necessary condition but not a sufficient condition. The reason is that the rock magnetic character of the remanence is often stabilized by heating in the laboratory, and this often makes it much easier to recover the correct intensity of the laboratory field in the second run. Due to this, we put the highest priority on the fact that the change of ARM due to heating is reasonably small as a criterion of accepting the results. Tentatively, only those results giving ARM1/ARM2 of 0.7-1.4 were accepted in this study.

Paleosecular variation is summarized as inclination, declination, and paleointensity versus lava position in Fig. 6 for the younger Whakapapa Formation (a) and the older Te Herenga Formation (b). Variation curves of inclination and declination seem to show some successive change. However, serial correlation was not detected at $5 \%$ confidence level by the test of Watson and Beran (1967) in any of the successive lava series. This suggests that the variation curves may be simply a random sampling of the paleosecular variation. Then there are some peculiar features among the variation curves. The mean paleodirection $\left(I=-54.3^{\circ}, D=22.1^{\circ}, \alpha_{95}=3.6^{\circ}\right)$ of the older Te Herenga Formation is easterly deflected by more than $20^{\circ}$. As any tectonic rotation has not been detected by paleomagnetism for such young field of New Zealand (Cox, 1969; Tanaka et al., 1996), it is possible that the effect of paleosecular variation has not been fully averaged out. The small angular standard deviation (ASD) of $8.9^{\circ}$ also indicates lack of time coverage long enough to obtain the dipole direction. Although New Zealand is contained in the longitudinal region of small ASD for the last several million years according to Shibuya et al. (1995), the ASD obtained in this study is even smaller. Another peculiar feature observed in the paleosecular variation curves is that there are two groups of paleointensities; about $45 \mu \mathrm{T}$ and about $20 \mu \mathrm{T}$. 


\section{(a) Whakapapa Formation (32+12 ka)}
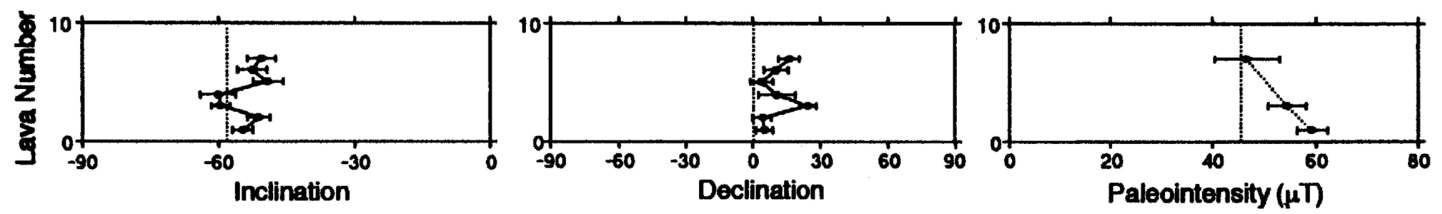

(b) Te Herenga Formation (229 $135 \mathrm{ka})$
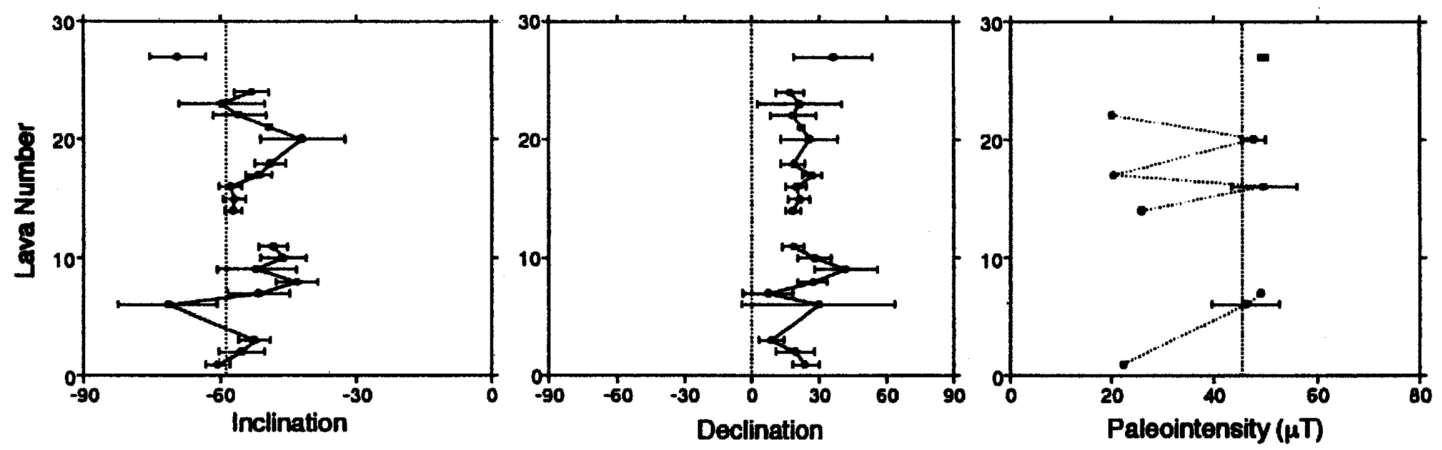

Fig. 6. Paleosecular variation curves of inclination, declination, and intensity are shown against stratigraphy for the Whakapapa Formation (a) and the Te Herenga Formation (b). Although there seems to be a trend of successive change of paleodirection in some portion of the lava sequences, no serial correlation was detected among the paleodirections.

It is not surprising, however, that paleointensity varies by a factor of 2 due to the westward drift of non-dipole fields.

\section{Conclusions}

K-Ar ages of andesite lavas of the Whakapapa and the Te Herenga Formations of the Quaternary Ruapehu Volcano, New Zealand were determined by the amplitude method. Averaged ages of $32 \pm 12$ ka and $229 \pm 35$ ka were obtained for the former and latter, respectively, with good repeatability of the results, indicating the superiority of this method over the conventional method using an ${ }^{38} \mathrm{Ar}$ spike. Intensive paleointensity experiments were made by the Shaw method with subsidiary Thellier method experiments, incorporating the additional double heating technique recently suggested by Tsunakawa and Shaw (1994). It is suggested that important factors to obtain correct paleointensities are, (1) reasonable values for the ratio of ARM1/ARM2, (2) multi-specimen experiment, and (3) practice of a double heating test. Serial correlation was not detected in the curves of paleodirection at any lava sections. The random nature of the paleodirections suggests not so short time coverage of the lava sections, and yet the dipole direction was not obtained by averaging the 20 results from the older series.

We thank Ichiro Kaneoka of Earthquake Research Institute of the University of Tokyo for instruction and use of facilities for potassium measurements. Discussions on the paleointensity analysis with Masaru Kono of the University of Tokyo and Hideo Tsunakawa of Tokyo Institute of Technology are acknowledged. We appreciate many comments given by the reviewers (Gillian M. Turner and Hidetoshi Shibuya), which 


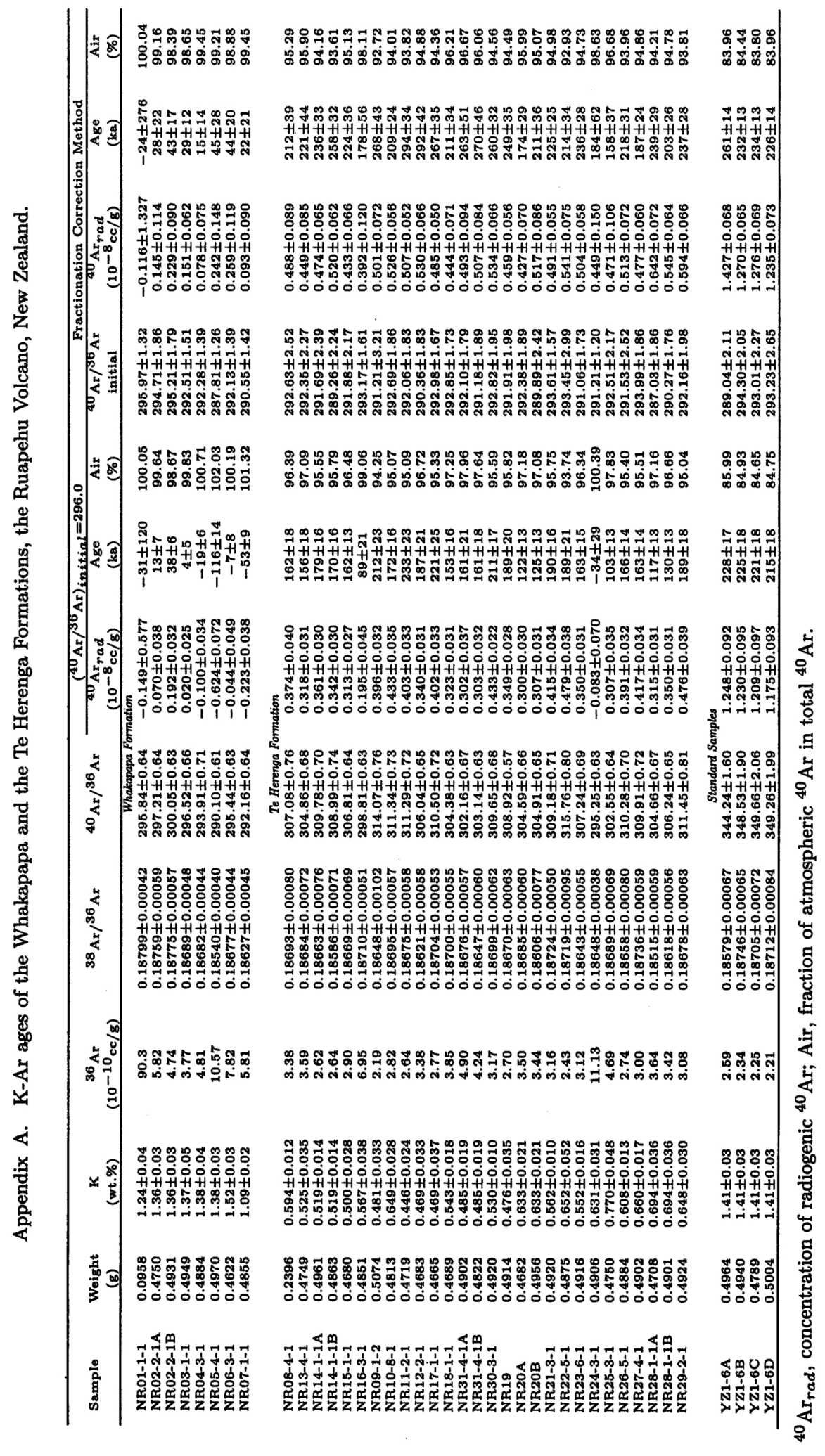




\begin{tabular}{|c|c|c|c|c|c|c|c|c|c|}
\hline 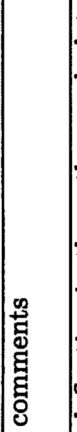 & 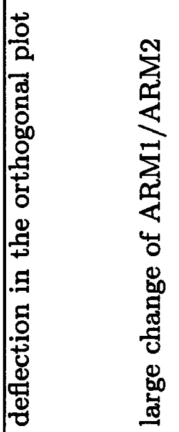 & & & & & 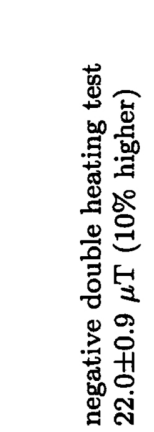 & 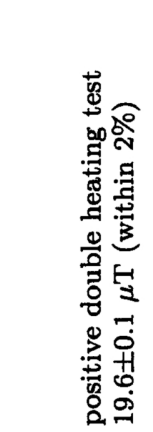 & 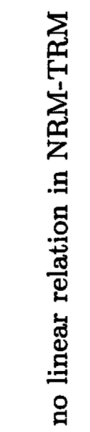 & \\
\hline 雲, & تص & 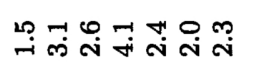 & $ت \stackrel{\infty}{ت} \stackrel{0}{0}$ & $\stackrel{\ominus}{\dot{\varphi}}$ & 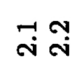 & 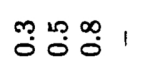 & Ṇ恶芯 & $\exists 1$ & $\stackrel{0}{0} 0$ \\
\hline$\left[\begin{array}{c}\mathrm{G} \\
3\end{array}\right.$ & 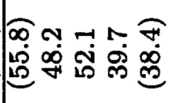 & 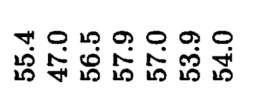 & 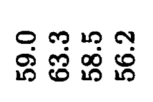 & 붕요 & ஸุ & 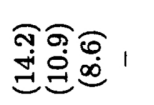 & 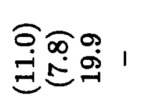 & $\overrightarrow{\dot{s}} 1$ & 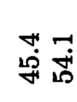 \\
\hline 저료 & 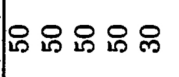 & 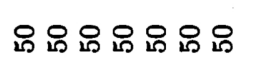 & 있온요맘 & 용요 & 욤요 & 유 ฉำ 유 & ㅇํㅇ్ㅀ ్ㅗ & 암요 1 & 요ㅇㅛㅛ \\
\hline $\mid \frac{2}{<}$ & 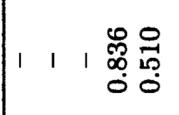 & 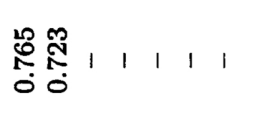 & $\begin{array}{l}\text { 유 } \\
\substack{\infty \\
0} \\
0 \\
0\end{array}$ & 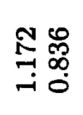 & $\begin{array}{l}\text { 足 } \\
\infty \\
0 \\
0 \\
0\end{array}$ & 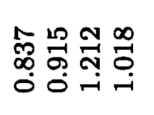 & 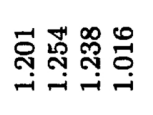 & $\begin{array}{l}\hat{5} \\
\substack{1 \\
\infty \\
0} \\
0\end{array}$ & 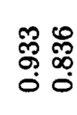 \\
\hline$\infty$ & 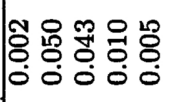 & 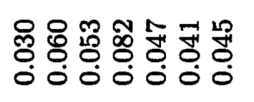 & 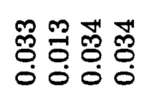 & $\begin{array}{l}0 \\
-1 \\
0 \\
0\end{array}$ & 쿵웅 & 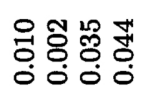 & 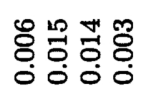 & $\stackrel{m}{0}_{0}^{\infty}$ & $\begin{array}{l}\text { 음 } \\
0 \\
0 \\
0\end{array}$ \\
\hline 0 & 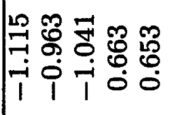 & 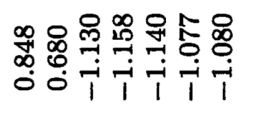 & 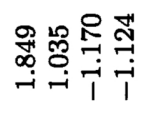 & $\stackrel{2}{\stackrel{2}{\dddot{l}}}$ & 足 & 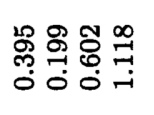 & 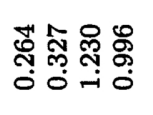 & 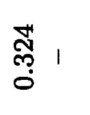 & 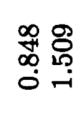 \\
\hline \& & 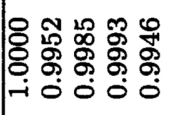 & 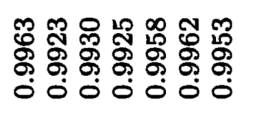 & 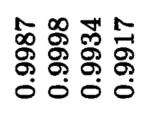 & 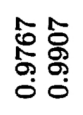 & $\begin{array}{l}\text { స్ㅇㅇㅇ } \\
\text { ợ } \\
0\end{array}$ & 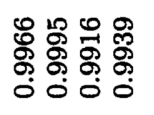 & 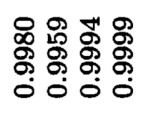 & 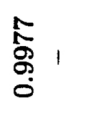 & 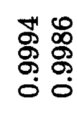 \\
\hline 8 & $\forall 0 \sim \infty \forall$ & $\infty \forall r L N$ & 음ㅇㅇㅇㅡ & $\sim \infty$ & $\infty \infty$ & エON & 0079 & 1 & 으으 \\
\hline 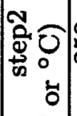 & 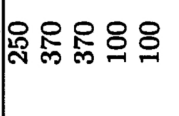 & 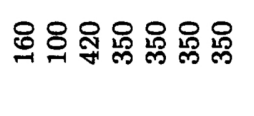 & 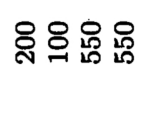 & : & 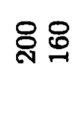 & 유유유. & 윙유융 & \& 1 & 怘永 \\
\hline 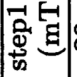 & 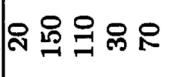 & ৪ ৪ 이욤 유 유 & 용ํㄱㅇㅠ & ৪ & 잉 & 융ㅇㅇㅛ & 오잉요 & 81 & $\infty 8$ \\
\hline$E$ & 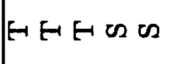 & DUEHEHE & OS OS H & os us & us & 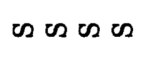 & $\cos \theta \cos$ & en & थs \\
\hline$-\frac{\text { a }}{4}$ & 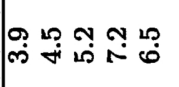 & ஸุ & 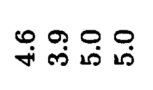 & $\stackrel{m}{\sim} \stackrel{\sim}{i}$ & 욤 & 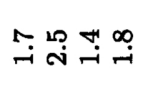 & 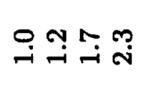 & im & ఝั ஸे \\
\hline $\mid$ & 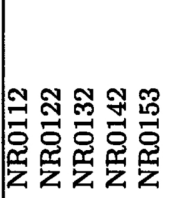 & 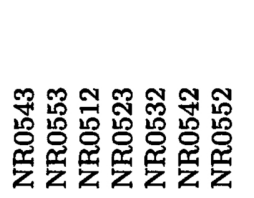 & 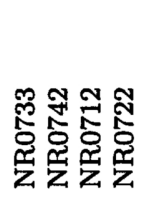 & 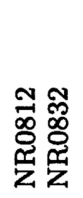 & 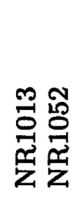 & 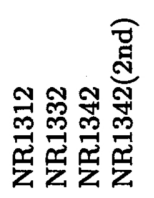 & 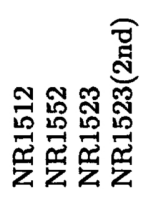 & 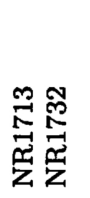 & 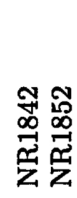 \\
\hline
\end{tabular}




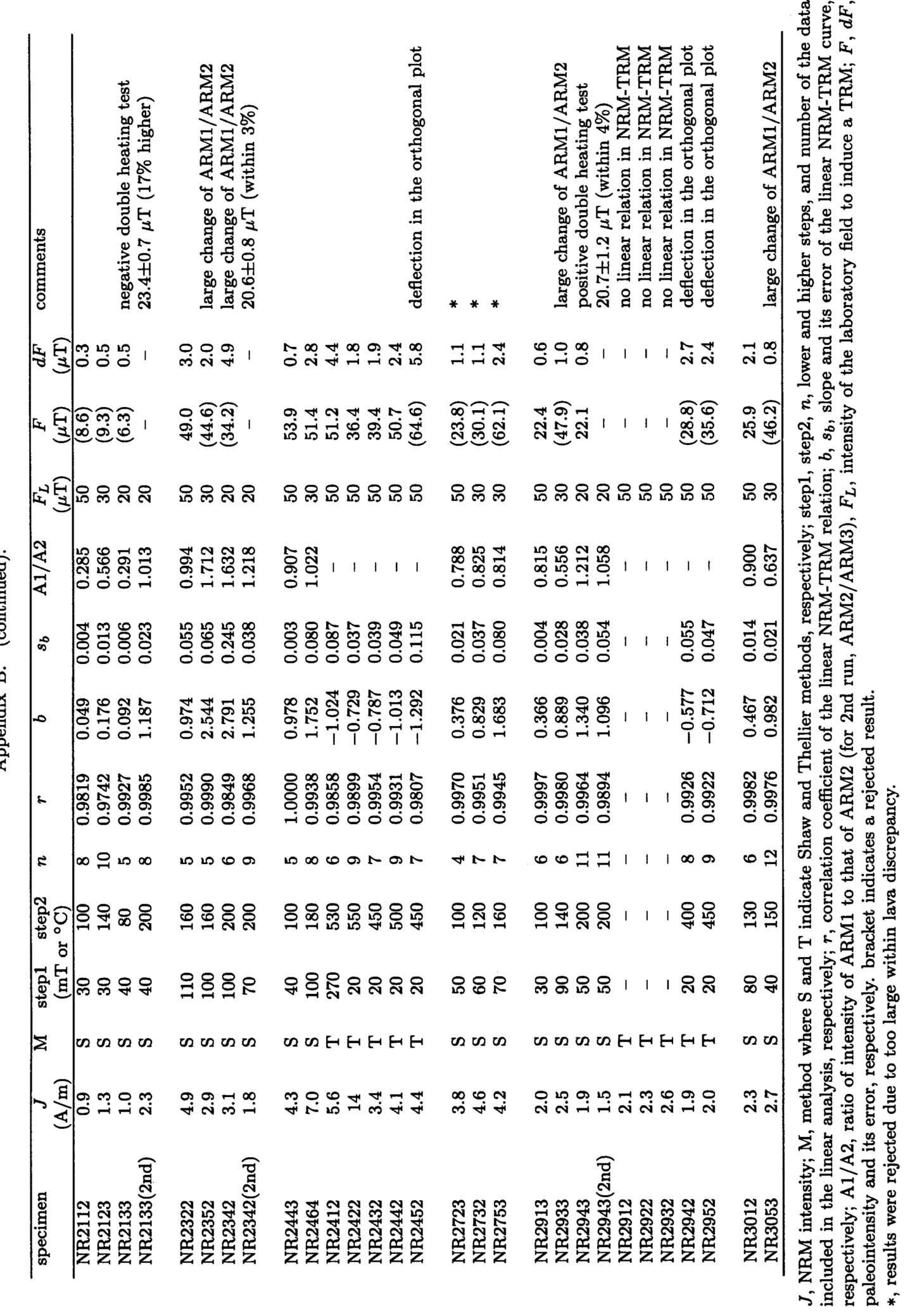


greatly improved the manuscript.

\section{REFERENCES}

Ando, A., H. Kurasawa, T. Ohmori, and E. Takeda, 1971 compilation of data on rock standards JG-1 and JB-1 issued from the Geological Survey of Japan, Geochem. J., 5, 151-164, 1971.

Cole, J. W., Distribution and tectonic setting of late Cenozoic volcanism in New Zealand, in Late Cenozoic Volcanism in New Zealand, edited by I. E. M. Smith, 371pp., The Royal Society of New Zealand Bulletin 23, Wellington, 1986.

Cox, A., A paleomagnetic study of secular variation in New Zealand, Earth Planet. Sci. Lett., 6, $257-267,1969$.

Dalrymple, G. B. and M. A. Lanphere, Potassium-Argon Dating-Principles, Techniques and Applications to Geochronology, 258pp., W. H. Freeman and Company, San Francisco, 1969.

Fisher, R. A., Dispersion on a sphere, Proc. Roy. Soc., A217, 295-305, 1953.

Gillot, P. Y., J. Labeyrie, C. Laj, G. Vallandas, G. Guerin, G. Poupeau, and G. Delibrias, Age of the Laschamp paleomagnetic excursion revisited, Earth Planet. Sci. Lett., 42, 444-450, 1979.

Hackett, W. R. and B. F. Houghton, A facies model for a Quaternary andesitic composite volcano: Ruapehu, New Zealand, Bull. Volcano., 51, 51-68, 1989.

Kaneoka, I., Rare gas isotopes and mass fractionation: an indicator of gas transport into or from a magma, Earth Planet. Sci. Lett., 48, 284-292, 1980.

Kono, M., Reliability of palaeointensity methods using alternating field demagnetization and anhysteretic remanence, Geophys. J. R. astr. Soc., 54, 241-261, 1978.

Kristjánsson, L., Some statistical properties of palaeomagnetic directions in Icelandic lava flows, Geophys. J. R. astr. Soc., 80, 57-71, 1985.

Mankinen, E. A., M. Prévot, C. S. Grommé, and R. S. Coe, The Steens Mountain (Oregon) geomagnetic polarity transition 1. Directional history, duration of episodes, and rock magnetism, J. Geophys. Res., 90, 10393-10416, 1985.

McFadden, P. L. and M. W. McElhinny, The combined analysis of remagnetization circles and direct observations in paleomagnetism, Earth Planet. Sci. Lett., 87, 161-172, 1988.

Nagao, K., A. Ogata, Y. Miura, J. Matsuda, and S. Akimoto, Highly reproducible 13 and 17 ka K-Ar ages of two volcanic rocks, Geochem. J., 25, 447-451, 1991.

Nagao, K., A. Ogata, Y. N. Miura, and K. Yamaguchi, Ar isotope analysis for K-Ar dating using two ModifiedVG5400 mass spectrometers-I: Isotope dilution method, J. Mass Spectrom. Soc. Jpn., 44, 39-61, 1996.

Nagata, T., Y. Arai, and K. Momose, Secular variation of the geomagnetic total force during the last 5000 years, J. Geophys. Res., 68, 5277-5281, 1963.

Pesonen, L. J. and H. C. Halls, Geomagnetic field intensity and reversal asymmetry in late Precambrian Keweenawan rocks, Geophys. J. R. astr. Soc., 73, 241-270, 1983.

Rolph, T. C. and J. Shaw, A new method of paleofield magnitude correction for thermally altered samples and its application to Lower Carboniferous lavas, Geophys. J. R. astr. Soc., 80, 773-781, 1985.

Shaw, J., A new method of determining the magnitude of the palaeomagnetic field, Application to five historic lavas and five archaeological samples, Geophys. J. R. astr. Soc., 39, 133-141, 1974.

Shibuya, H., J. Cassidy, I. E. M. Smith, and T. Itaya, Paleomagnetism of young New Zealand basalts and longitudinal distribution of paleosecular variation, J. Geomag. Geoelectr., 47, 1011-1022, 1995.

Stipp, J. J., The geochronology and petrogenesis of the Cenozoic volcanics of the North Island, New Zealand, Ph.D. Thesis, Australian National University, Canberra, 1968.

Tanaka, H., G. M. Turner, B. F. Houghton, T. Tachibana, M. Kono, and M. O. McWilliams, Palaeomagnetism and chronology of the central Taupo Volcanic Zone, New Zealand, Geophys. J. Int., 124, 919-934, 1996.

Thellier, E. and O. Thellier, Sur l'intenité du champ magnetique terrestre dans le passé historique et géologique, Ann. Geophys., 15, 285-376, 1959.

Tsunakawa, H. and J. Shaw, The Shaw method of palaeointensity determinations and its application to recent volcanic rocks, Geophys. J. Int., 118, 781-787, 1994.

Watson, G. S. and R. J. Beran, Testing a sequence of unit vectors for serial correlation, J. Geophys. Res., 72, 5655-5659, 1967.

Wilson, C. J. N., Taupo's atypical arc, Nature, 379, 27-28, 1996.

Zijderveld, J. D. A., A. C. demagnetization of rocks: Analysis of results, in Method in Paleomagnetism, edited by D. W. Collinson and K. M. Creer, pp. 254-286, Elsevier, New York, 1967. 